\title{
Isolation and Identification of Cellulolytic Bacteria Symbiont from Various Termites on Different Nest Type in Bukit Baka Bukit Raya National Park, West Kalimantan, Indonesia
}

\author{
Mohamad Rusdi HIDAYAT \\ Institute for Industrial Research and Standardization of Pontianak, Indonesian Ministry of Industry, \\ Pontianak, West Kalimantan, Indonesia
}

(Corresponding author's e-mail: m.rusdi.hidayat@gmail.com)

Received: 11 September 2020, Revised: 14 December 2020, Accepted: 7 January 2021

\begin{abstract}
The microbial symbiotic community in the digestive tract of termites is reportedly influenced by the taxonomy and feeding habit of the host. Both factors are strongly correlated with the nest type. This study aimed to isolate the cellulolytic bacteria from termite's digestive tract on different nest types and characterize and identify the potential isolates. The research methods included termite sampling conducted in Bukit Baka Bukit Raya National Park (BBBRNP), Melawi, West Kalimantan, isolation of cellulolytic bacteria from termites' gut, endoglucanase activity test, biochemical characterization, and DNA analysis based on the amplification of 16S rRNA gene. Thirty isolates from 6 different species of termites on three different nest types were successfully isolated. Sixteen potential endoglucanase bacterial isolates were tested in terms of their endoglucanase activity. The cellulolytic index measured from those isolates ranged from 1.162 - 4.894. Three isolates (MRH.13.S, MRH.13.AF, and MRH.13.O2) with the highest cellulolytic index on each nest type were identified. The analysis of 16S rRNA gene using BLAST (Basic Local Alignment Search Tool for Nucleotides) revealed that isolate MRH.13.S had the closest relationship with Bacillus tequilensis (99\% homology). Based on biochemical characterization, MRH.13.AF and MRH.13.O2 isolates were related to Bacillus spp.
\end{abstract}

Keywords: Bacillus, Bukit Baka-Bukit Raya National Park, Endoglucanase producing bacteria, Termite intestinal tract

\section{Introduction}

Lignocellulose is one of the most important renewable raw materials for modern industrial societies. Lignocellulosic materials are mostly generated as waste byproducts from agricultural activities, plantations, and agro-based industries. Recently, research on lignocellulosic biomass has increased due to its potential and renewable nature. Lignocellulosic biomass has the potential to be converted into highvalue products such as biofuels, fine chemicals, and cheap energy sources for fermentation and enzyme production [1-3]. The biodegradation of the lignocellulosic materials is a key process for lignocellulose bioconversion into high-value products. However, the biodegradation of lignocellulose is a complex process involving various factors including the microorganisms, biomass sources, and technology used [4].

Termite is one of the organisms capable of digesting lignocellulose with the help of its symbiotic cellulolytic microorganisms in their digestive tract. Termites gut microbiomes could degrade lignocellulose substrate from wheat straw up to $45 \%(\mathrm{w} / \mathrm{w})$ of degradation in a bioreactor [5]. Furthermore, bacterial diversity in the digestive tract of termite Reticulitermes includes more than 15 bacterial phyla dominated by Spirochaetes, Bacteroidetes, and Firmicutes [6]. 
In addition, since termite intestinal tract had a microoxic periphery, termite intestinal tract is not completely anoxic. This condition results in various cellulolytic bacteria (e.g., aerobic, microaerophilic, facultatively anaerobic, and anaerobic) present in termites' gut [7,8]. Various cellulolytic bacterial isolates have been isolated from different termites species such Acinetobacter, Pseudomonas, Staphylococcus, Enterobacteriaceae and Bacillaceae from Microcerotermes diversus [9]; Bacillus sp., Citrobacter freundii, Pseudomonas aeruginosa, Salmonella entrica, Enterococcus casseliflavus, Staphylococcus gallinarum and Serratia marcescens from Odontotermes formosanus [10]; and Bacillus megaterium and Paracoccus yeei from Macrotermes gilvus [11].

Although there are many studies related to termite symbionts, particularly cellulolytic microorganisms, studies that correlate a certain type of nest with the cellulolytic microorganism symbionts are limited. Meanwhile, different nest types are closely related to the species, feeding habits, and nest-building materials. Therefore, differences in nest type might affect the abundance and diversity of cellulolytic microorganisms in the intestinal tract of termites. A study by Rosengaus et al. showed differences in the symbiotic microbial richness in the nest and on the cuticle of drywood termite and dampwood termite [12]. In addition, the nest materials contain diverse kinds of bacteria but has comparatively less fungus [13].

The termites in this study were taken from BBBRNP. BBBRNP is a conservation area located in the heart of Borneo Island. The area is administratively located in West Kalimantan and Central Kalimantan Province, Indonesia. It has a total area of $181.090 \mathrm{Ha}$. It generally represents a tropical rainforest and known for its high biodiversity [14]. In the sampling sites, various types of termites were present. The termites are could be found foraging in open air all day, without any significant predators.

This study aimed to isolate and identify potential cellulolytic bacteria from termite intestinal tract on different nest types from BBBRNP. In this study, the isolation and culturing process were conducted in aerobic conditions to obtain aerobic cellulolytic bacterial isolates because aerobic process is preferable for industrial applications.

\section{Materials and methods}

\section{Termites sampling}

Termites were collected from a tropical rainforest in BBBRNP in Melawi district, West Kalimantan Province, Indonesia. Sampling sites in the BBBRNP were in the dipterocarp forest ecosystem (Figure 1). Annual rainfall in this area is more than $3,000 \mathrm{~mm}$ per year without a distinctive dry season [15]. Other environmental characteristics of the forest site during termites were recorded (Table 1). A random sampling method was used in this study. A total of 6 samples representing three types of termite nests (i.e., soil, wood, and arboreal) were collected. The termites were taken along with the nest. Parts of the termites' nests were collected and put in a container box. The termites in the nests were then maintained for further use by controlling the humidity and temperature in the containers by using wet paper so that the condition was similar to their original habitat. Some of the soldier caste termites were preserved in 70 $\%$ ethanol for identification.

Table 1 Environmental characteristics at the sampling site.

\begin{tabular}{lc}
\hline \multicolumn{1}{c}{ Parameter } & Characteristics \\
\hline Habitat/Ecosystem & Lowland dipterocarp primary forest \\
Coordinate & $\mathrm{S} 00^{\circ} 36^{\prime} 06.3^{\prime \prime} ; \mathrm{E} 112^{\circ} 14^{\prime} 43.7^{\prime \prime}$ \\
Temperature & $27^{\circ} \mathrm{C}$ \\
Humidity $(\mathrm{RH})$ & $99 \%$ \\
Soil $\mathrm{pH}$ & 6.5 \\
Altitude & $364 \mathrm{~m} \mathrm{dpl}$ \\
\hline
\end{tabular}




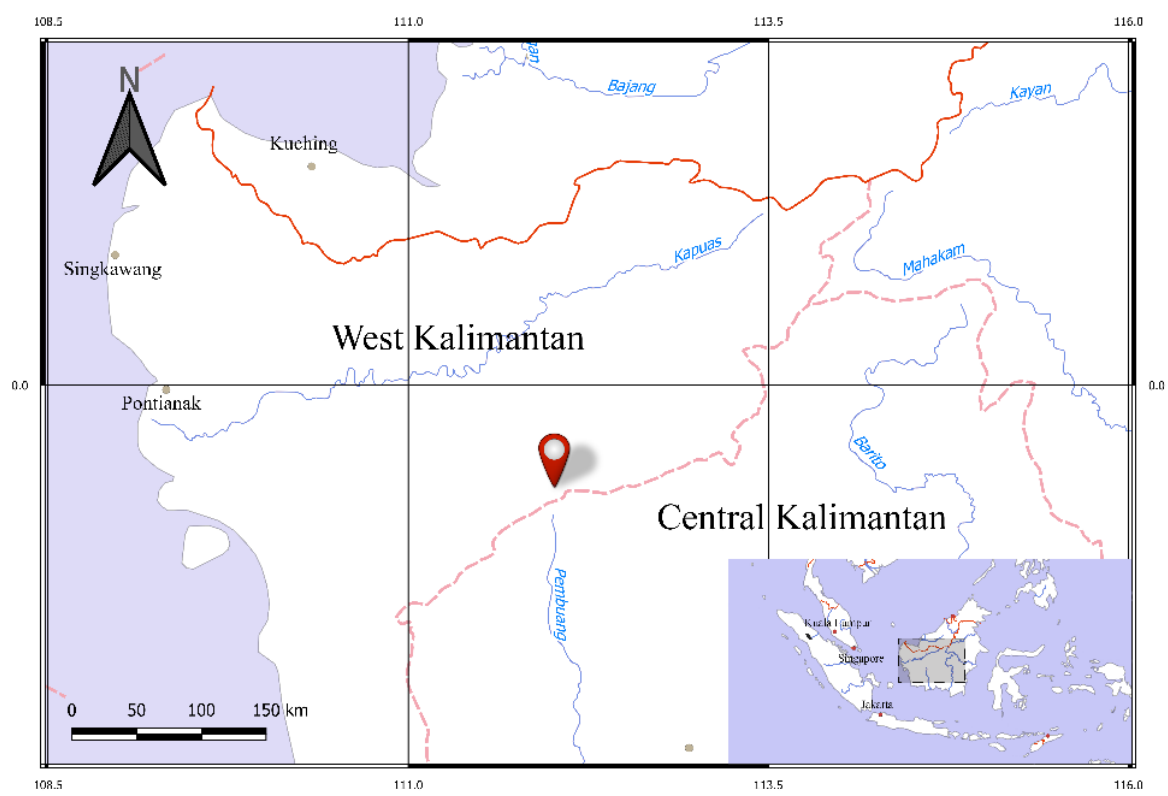

Figure 1 A western part of Borneo island map, termite sampling site is marked by a map pin icon.

\section{Identification of termites}

Termites were identified and sorted to species level based on the termite identification keys. Soldier castes of the termites were identified using identification key references [16-18]. Main morphological characteristics or body parts used for identification are heads, antennal segments, fontanelle, mandibles, postmentum, and pronotum.

\section{Isolation of cellulolytic bacteria}

Termites taken for this step were not more than 7 days since being taken from the BBBRNP. Carboxymethyl cellulose (CMC) was used for cellulolytic bacteria isolation from termites intestinal tract [19]. Bacteria isolation procedure was conducted under aseptic conditions. Ten worker termites were surface sterilized with $70 \%$ ethanol. After that, the termites were rinsed with distilled water and air-dried for approximately $1 \mathrm{~min}$. Termite's intestinal tracts were then picked with sterilized tweezers and mixed with $10 \mathrm{~mL}$ of $0.85 \% \mathrm{NaCl}$. Next, $0.5 \mathrm{~mL}$ of the suspension was added to $4.5 \mathrm{~mL}$ medium containing 5 $\mathrm{g} / \mathrm{L} \mathrm{CMC}$ and $0.2 \mathrm{~g} / \mathrm{L}$ of yeast extract, then incubated at $30{ }^{\circ} \mathrm{C}$ for 3 days. After incubation, $1 \mathrm{~mL}$ of the culture was spread on the nutrient agar or CMC agar. The plates were then incubated again for $24 \mathrm{~h}$ at room temperature. Pure bacterial isolates were obtained by several subsequent culturing and plating.

\section{Endoglucanase activity test}

A rapid method for detecting microbial cellulases using Gram's iodine was used to screen potent endoglucanase-producing bacteria [20]. The isolates were grown on CMC agar plates at $28{ }^{\circ} \mathrm{C}$ for $48 \mathrm{~h}$. CMC plates were then flooded with Gram's iodine for $3-5 \mathrm{~min}$ to reveal the cleared zones. The formation of a clear zone indicates the presence of endoglucanase. Next, endoglucanase potential of the positive isolates was assessed by measuring cellulolytic index. The cellulolytic index was calculated by measuring the ratio of the clear zone diameter to the colony diameter. Isolates with a cellulolytic index greater than 1.50 were considered to be potential cellulose producers [21]. The measurements were conducted in duplicate. 


\section{Biochemical characterization}

The isolates that have the highest cellulolytic index from each termite nest type were characterized using API $50 \mathrm{CH}$ kit (BIOMERIEUX, FRANCE). The API $50 \mathrm{CH}$ is a standardized system that associates the fermentation of 50 carbohydrates to bacteria species. The system is usually used for the identification of Bacillus, Lactobacillus, and related genera by using API identification software database (API LAB PLUS).

\section{S rRNA analysis}

Isolates that had the highest cellulolytic index from each termite nest type were also used for $16 \mathrm{~S}$ rRNA analysis. Genomic DNA was isolated using the manufacture's kit protocols (Qiagen, USA). The isolated DNA was amplified by PCR reaction using primers 9F forward primer (5GAGTTTGATCCTGGCTCAG-3') and 1541R reverse primer (5-AAGGAGGTGATCCAGCC-3') [22]. Polymerase chain reaction (PCR) was performed using Takara PCR Thermal Cycler DiceTM. Each reaction mixture $(25 \mu \mathrm{L})$ contained $2 \mu \mathrm{L}$ of forward and reverse primers $(0.5 \mathrm{mM}), 12.5 \mu \mathrm{L} 2 \mathrm{X}$ master mix, $2 \mu \mathrm{L}$ DNA templates, and $6.5 \mu \mathrm{L}$ nuclease-free water. The condition for amplification reactions was as follows: $95^{\circ} \mathrm{C}$ for $3 \mathrm{~min}, 50$ cycles consisting of $95^{\circ} \mathrm{C}$ for $30 \mathrm{sec}, 62^{\circ} \mathrm{C}$ for $30 \mathrm{sec}, 72{ }^{\circ} \mathrm{C}$ for $45 \mathrm{sec}$, and final extension at $72{ }^{\circ} \mathrm{C}$ for $7 \mathrm{~min}$. PCR products were then sequenced using a DNA sequencer (ABI PRISM 300). The 16S rRNA sequences obtained were analyzed using BLAST (http://www.ncbi.nlm.nih.gov/BLAST) on July 24, 2018. Phylogenetic analysis was carried out using neighbor-joining method at 1,000X bootstraps using Clustal X version 2.1 software [23].

\section{Results and discussion}

\section{Collection and identification of termite}

The isolation of cellulolytic bacteria directly from termites in a tropical rain forest is still limited because of the difficulties in the preparation. In addition, arboreal termites are usually difficult to find outside of the forest areas. Termite collection in BBBRNP was conducted at KM 37 site, a reserved area frequently used for various research activities. Other areas in the national park are still unexplored by humans, even by the locals, due to extreme terrains.

During the survey conducted beforehand, it was observed that termites obtained from the BBBRNP were very sensitive to temperature changes, so that termites and their nests were collected in the afternoon and then taken directly to the laboratory at night (around $420 \mathrm{~km}$ ). The termites were less stressed because of sudden changes in temperature, humidity or other environmental factors. In the laboratory, the termites were maintained for the next step and identification process.

A total of 6 species of termites were used in this study. Each nest type was represented by 2 species. Identification results showed that the termites consisted of 1 family of Termitidae, 3 sub-families, and 5 genera (Table 2).

Table 2 Termite species collected at BBBRNP.

\begin{tabular}{clllc}
\hline No. & Nest type & Sub families & Species & Feeding group \\
\hline 1. & Soil & Termitinae & Termes comis & III \\
2. & Soil & Termitinae & Dicuspiditermes garthwaitei & III \\
3. & Wood & Termitinae & Synhamitermes quadriceps & N/A \\
4. & Wood & Nasutitermitinae & Havilanditermes proatripennis & II \\
5. & Arboreal & Nasutitermitinae & Bulbitermes borneensis & II \\
6. & Arboreal & Nasutitermitinae & Bulbitermes parapusillus & II \\
\hline
\end{tabular}


Based on their feeding groups, termites collected belonged to feeding group III (Termes \& Dicuspiditermes) and II (Bulbitermes \& Havilanditermes), while Synhamitermes cannot be determined due to the lack of data of the genus (Table 2). Group II contains some Termitidae species that have a wide range of feeding habits, including wood-feeding, litter-feeding and microepiphyte-feeding. Meanwhile, group III includes species of Termitidae that feed on organic-rich soil or highly decayed soillike wood [24].

\section{Isolation of cellulolytic bacterial isolates}

Cellulolytic bacteria are groups of bacteria that could secrete cellulases enzymes to break the glycosidic bonds of cellulose microfibrils, resulting in the release of oligosaccharides and improving cellulose digestibility [25]. In this study, 30 cellulolytic bacterial isolates were isolated from the intestinal tract of the 6 termite species after enrichment in CMC medium. Sixteen isolates were found to have clear zones, while others did not produce clear zones. Most of the isolates that produce clear zones came from soil termites, followed by wood termites and arboreal termites consecutively (Table 3). Dicuspiditermes garthwaitei was termite species that had the most isolated cellulolytic isolates.

Table 3 The number of cellulolytic bacterial isolates recovered from the intestinal tract of various termites on the different nest type from tropical rainforest in BBBRNP, West Kalimantan Province, Indonesia.

\begin{tabular}{lccc}
\hline Termite species & $\begin{array}{c}\text { No. of isolates with } \\
\text { clear zone }\end{array}$ & $\begin{array}{c}\text { No. of isolates without } \\
\text { clear zone }\end{array}$ & Total isolates \\
\hline Soil Nest & 4 & 1 & 5 \\
Termes comis & 6 & 1 & 7 \\
Dicuspiditermes garthwaitei & & & 6 \\
Wood Nest & 0 & 6 & 4 \\
Synhamitermes quadriceps & 2 & 2 & 6 \\
Havilanditermes proatripenis & & 2 & 2 \\
Arboreal Nest & 4 & 2 & 30 \\
Bulbitermes borneensis & 0 & & \\
Bulbitermes parapusillus & & & \\
\hline Total & & & \\
\hline
\end{tabular}

These results might be related to the area around the nests and the nest material. A research by Postava-Davignon concluded that arboreal nester termites have lower microbial loads and diversity than their surrounding soils [26]. Additionally, another study showed that colony forming units (CFUs) recorded from the dry wood termites nest material was low (fewer than $60 \mathrm{CFUs} / \mathrm{g}$ ), and comparatively high (800 CFUs/g) in the damp wood species [12]. However, the results of this study need further confirmation since the results among species in the same nesting type are varied.

Furthermore, studies on symbiotic microorganism in Arthropod are still continuously performed until today because Arthropod groups are known to have a complex system with its symbiotic microorganisms in their digestive tract. Those symbiotic microorganisms are closely related to the species and diet of the organism. Regarding its cellulolytic bacterial symbionts, some Arthropods such as beetles and earthworms have various cellulolytic bacteria in their digestive tract. A study by Shankar et al. had acquired 15 cellulolytic bacterial isolates from the midgut of earthworm Eudrilus eugeniae [27]. In the beetle larvae hindgut of Holotrichia parallela (Coleoptera), 93 cellulolytic bacterial isolates were found [28]. Moreover, isolation of cellulolytic bacteria from intestinal tract of termite Coptotermes curvignathus and Coptotermes formosanus results in 5 and 4 isolates [19,29]. 


\section{Endoglucanase activity test}

Cellulolytic activity measurement showed that bacterial isolates obtained in this study have a cellulolytic index in the range of $1.162-4.894$ (Table 4). Isolate that had the highest cellulolytic index was MRH.13.S, isolated from T. comis; followed by MRH.13.AL isolated from D. garthwaitei, MRH 13.AF from H. proatripenis, and MRH.13.O2 from B. borneensis.

The cellulolytic activity result in this study was higher than the isolates obtained from Macrotermes gilvus [11] or isolates from various invertebrates [30]. Next, isolates that had the highest cellulolytic index on each nest type (i.e., MRH.13.S, MRH.13.AF, and MRH.13.O2) were used for biochemical characterization and identification based on their 16S rRNA. In soil termite, MRH.13.S was selected not only for its higher cellulolytic index, but also because it grow faster than other isolates.

Table 4 Cellulolytic index of endoglucanase producing bacterial isolates from intestinal tract of various termite on different nest type collected from BBBRNP.

\begin{tabular}{|c|c|c|c|c|c|c|c|c|}
\hline \multicolumn{3}{|c|}{ Soil } & \multicolumn{3}{|c|}{ Wood } & \multicolumn{3}{|c|}{ Arboreal } \\
\hline Termite & Isolate & $\begin{array}{l}\text { Cellulolytic } \\
\text { Index }\end{array}$ & Termite & Isolate & $\begin{array}{l}\text { Cellulolytic } \\
\text { Index }\end{array}$ & Termite & Isolate & $\begin{array}{l}\text { Cellulolytic } \\
\text { Index }\end{array}$ \\
\hline $\mathrm{TC}$ & MRH.13.G & $2.21 \pm 0.25$ & HP & MRH.13.AF* & $3.07 \pm 0.71$ & $\mathrm{BB}$ & MRH.13.O1 & $1.77 \pm 0.66$ \\
\hline $\mathrm{TC}$ & MRH.13.R & $1.35 \pm 0.09$ & HP & MRH.13.AG & $2.04 \pm 0.26$ & $\mathrm{BB}$ & MRH.13.O2* & $3.01 \pm 0.53$ \\
\hline $\mathrm{TC}$ & MRH.13.S* & $4.89 \pm 3.72$ & & & & $\mathrm{BB}$ & MRH.13.P & $1.88 \pm 0.84$ \\
\hline $\mathrm{TC}$ & MRH.13.AJ & $2.67 \pm 0.68$ & & & & $\mathrm{BB}$ & MRH.13.AH & $1.69 \pm 0.43$ \\
\hline DG & MRH.13.K & $1.58 \pm 0.25$ & & & & & & \\
\hline DG & MRH.13.L & $2.66 \pm 0.44$ & & & & & & \\
\hline DG & MRH.13.U1 & $1.51 \pm 0.22$ & & & & & & \\
\hline DG & MRH.13.U2 & $1.16 \pm 0.11$ & & & & & & \\
\hline DG & MRH.13.AK & $1.22 \pm 0.05$ & & & & & & \\
\hline DG & MRH.13.AL & $3.38 \pm 2.02$ & & & & & & \\
\hline
\end{tabular}

TC (T. cormis), DG (D. garthwaitei), HP (H. proatripenis), BB (B. borneensis)

*: isolates selected for biochemical characterization and 16S rRNA analysis

In this study, a qualitative endoglucanase activity test using Gram Iodine was performed to determine the activity of endoglucanase in the isolate grown on CMC agar medium. Visualization of endoglucanase hydrolysis on CMC medium commonly use Congo Red. However, Gram Iodine solution was chosen because of the following considerations: a) Iodine materials are more readily available and less expensive than Congo Red; b) Gram Iodine test was shorter (3 - $6 \mathrm{~min}$ ) compared to Congo Red (30 min); and more importantly; c) Congo Red is a carcinogenic material [20]. In Iodine Gram's test, Iodine Gram solution binds to the 1,4-beta glycoside bond in the cellulose resulting in a brownish color. The clearing zones around the colony shows that cellulose has been unraveled into its monosaccharide because the 1,4-beta glycoside bond has been broken off by the endoglucanase produced by the bacterium [20].

Biochemical characterization and 16S rRNA analysis

All of the three isolates tested were bacilli and Gram-positive. Biochemical characterization showed that each isolate only differed in Methyl-D-glucoside, N-Acetyl-Glucosamine, and D-turanose utilization. MRH.13.S showed negative reactions to biochemical assay of Methyl-D-glucoside and D-turanose. MRH.13.AF showed positive reactions to biochemical assay of Methyl-D-glucoside and D-turanose. MRH.13.O2 showed positive reactions to biochemical assay of Methyl-D-glucoside and negative reactions to N-Acetyl-Glucosamine and D-turanose. All isolates utilized Glycerol, L-arabinose, Ribose, Glucose, Fructose, Mannose, Inositol, Mannitol, Sorbitol, Amygdalin, Arbutin, Esculin, Salicin, Cellobiose, Maltose, Mellibiose, Sucrose, Trehalose, Inulin, Raffinose, Starch, and Glycogen (Table 5). 
Comparison with the API database (https://apiweb.biomerieux.com) revealed that all of the isolates were Bacillus subtilis with homology at $99.8 \%$ for MRH.13 S and MRH.13 O2, and $97.4 \%$ for MRH.13.AF.

Biochemical characterization results showed that each isolate has different characteristics. Therefore, molecular characterization using 16S rRNA gene was required for further analysis.16S rRNA gene sequence could be used to identify bacteria that have deviated phenotypic strains. Mutations or base differences in the base sequence are used as a determinant for bacterium identification at the level of genus, species, or even strain. Nowadays, identification of bacteria based on sequence analysis of the 16S rRNA gene has been the main method for determining new species and strains [31].

Table 5 Biochemical characterization of the 3 potential isolates based on API $50 \mathrm{CH}$.

\begin{tabular}{|c|c|c|c|c|}
\hline \multirow{2}{*}{ No. } & \multirow{2}{*}{ Test } & \multicolumn{3}{|c|}{ Isolate } \\
\hline & & MRH.13.S & MRH.13.AF & MRH.13.02 \\
\hline 0 & Control & - & - & - \\
\hline 1 & Glycerol & + & + & + \\
\hline 2 & Erythritol & - & - & - \\
\hline 3 & D-arabinose & - & - & - \\
\hline 4 & L-arabinose & + & + & + \\
\hline 5 & Ribose & + & + & + \\
\hline 6 & D-xylose & - & - & - \\
\hline 7 & L-xylose & - & - & - \\
\hline 8 & Adonitol & - & - & - \\
\hline 9 & ß methyl-D-Xyloside & - & - & - \\
\hline 10 & Galactose & - & - & - \\
\hline 11 & Glucose & + & + & + \\
\hline 12 & Fructose & + & + & + \\
\hline 13 & Mannose & + & + & + \\
\hline 14 & Sorbose & - & - & - \\
\hline 15 & Rhamnose & - & - & - \\
\hline 16 & Dulcitol & - & - & - \\
\hline 17 & Inositol & + & + & + \\
\hline 18 & Mannitol & + & + & + \\
\hline 19 & Sorbitol & + & + & + \\
\hline 20 & Methyl-D-mannoside & - & - & - \\
\hline 21 & Methyl-D-glucoside & - & + & + \\
\hline 22 & N-Acetyl-Glucosamine & - & + & - \\
\hline 23 & Amygdalin & + & + & + \\
\hline 24 & Arbutin & + & + & + \\
\hline 25 & Esculin & + & + & + \\
\hline 26 & Salicin & + & + & + \\
\hline 27 & Cellobiose & + & + & + \\
\hline 28 & Maltose & + & + & + \\
\hline 29 & Lactose & - & - & - \\
\hline 30 & Melibiose & + & + & + \\
\hline 31 & Sucrose & + & + & + \\
\hline 32 & Trehalose & + & + & + \\
\hline 33 & Inulin & + & + & + \\
\hline 34 & Melezitose & - & - & - \\
\hline 35 & Raffinose & + & + & + \\
\hline 36 & Starch & + & + & + \\
\hline 37 & Glycogen & + & + & + \\
\hline
\end{tabular}




\begin{tabular}{rcccc}
\hline \multirow{2}{*}{ No. } & Test & & Isolate & \\
\cline { 3 - 5 } 38 & Xylitol & MRH.13.S & MRH.13.AF & MRH.13.O2 \\
39 & B Gentiobiose & - & - & - \\
40 & D-turanose & - & - & - \\
41 & D-lyxose & - & - & - \\
42 & D-tagatose & - & - & - \\
43 & D-fucose & - & - & - \\
44 & L-fucose & - & - & - \\
45 & D-arabitol & - & - & - \\
46 & L-arabitol & - & - & - \\
47 & Gluconate & - & - & - \\
48 & 2-Keto-Gluconate & - & - & - \\
49 & 5-Keto-Gluconate & - & - & - \\
\hline
\end{tabular}

Symbol of + and - represent the positive and negative reaction of isolates on substrate.

16S rRNAs gene is commonly used as a molecular marker because the molecules are ubiquitous with identical functions to all organisms. This molecule also varies according to its evolutionary distance. Therefore, it could be used as a good evolutionary chronometer. In addition, 16S rRNA molecule has several regions that vary and relatively conservative base sequences [31].

BLAST analysis results showed that isolate MRH.13.S had $99 \%$ close relationship with Bacillus tequilensis strain 10b (NR_104919.1). Isolates MRH.13.AF and MRH.13.O2 have $93 \%$ homology with several Bacillus species, including Bacillus nakamurai (NR_151897.1) and Bacillus subtilis subsp. subtilis strain 168 (NR_102783.2), respectively (Table 6). Low homology results on MRH.13.AF and MRH.13.O2 isolates might be due to the short sequence of 16S rRNA gene produced. The contig region of 16S rRNA gene from MRH.13.AF isolate was $239 \mathrm{bp}$ and MRH.13.O2 isolate was $245 \mathrm{bp}$; meanwhile MRH.13.S isolate was $1060 \mathrm{bp}$. However, utilization of short sequence of 16S rRNA gene for BLAST analysis also depend on targeted part of the gene or sub-regions used [32]. BLAST analysist result that generate a minimum of $93 \%$ homology might indicate that the targeted 16S rRNA gene is sufficient. According to Drancourt et al. based on $16 \mathrm{~S}$ rRNA sequence data, $\geq 99 \%$ homology indicates that the species compared are the same species, while $\geq 97 \%$ homology indicates that the isolates compared were in the same genus and 89 - $93 \%$ homology showed different species [33]. Usually, phylogenetic analysis was used to confirm this result.

Table 6 BLAST analysis result.

\begin{tabular}{llc}
\hline \multicolumn{1}{c}{ Isolate } & \multicolumn{1}{c}{$\begin{array}{c}\text { Closest relationship to species } \\
\text { [Genbank Accession Number] }\end{array}$} & \% homology \\
\hline MRH.13.S & Bacillus tequilensis strain 10b [NR_104919.1] & $99 \%$ \\
\hline MRH.13.AF & Bacillus nakamurai strain NRRL B-41091 [NR_151897.1] & $93 \%$ \\
& Bacillus velezensis strain FZB42 [NR_075005.2] & $93 \%$ \\
& Bacillus subtilis subsp. subtilis strain 168 [NR_102783.2] & $93 \%$ \\
& Bacillus subtilis strain IAM 12118 [NR_112116.2] & $93 \%$ \\
\hline MRH.13.O2 & Bacillus nakamurai strain NRRL B-41091 [NR_151897.1] & $93 \%$ \\
& Bacillus velezensis strain FZB42 [NR_075005.2] & $93 \%$ \\
& Bacillus subtilis subsp. subtilis strain 168 [NR_102783.2] & $93 \%$ \\
& Bacillus subtilis strain IAM 12118 [NR_112116.2] & $93 \%$ \\
\hline
\end{tabular}


http://wjst.wu.ac.th

The phylogenetic tree of the isolate MRH.13.S was shown in Figure 2. Phylogenetic analyses were not performed on the rest of the isolates due to low quality of sequences. Based on the phylogenetic tree, isolate MRH.13.S was in the same group with B. subtilis (AJ276351.1), B. tequilensis (NR_104919.1), and B. halotolerans (AM747812.1). This phylogenetic tree was in accordance with BLAST results.

The cellulolytic bacteria in the termite intestinal tract are facultatively anaerobic or microaerophilic bacteria. Among the cellulose degraders, Bacilli form a significant portion of the intestinal microbial community of termite and other soil invertebrates. In Zootermopsis angusticollis, the titres of Bacillus genera is up to $107 \mathrm{~mL}^{-1}$ of gut contents [34]. Microbial analysis using culture-dependent and cultureindependent methods in termite gut and fungus comb of fungus-growing termite Odontotermes formosanus revealed that the predominant bacterial cultivars are belong to the genus Bacillus (Phylum Firmicutes) [35]. Bacillus cereus, including 3 other cellulolytic bacterial species, has also been isolated from intestinal tract of the subterranean termite Psammotermes hypostoma Desneux [36].

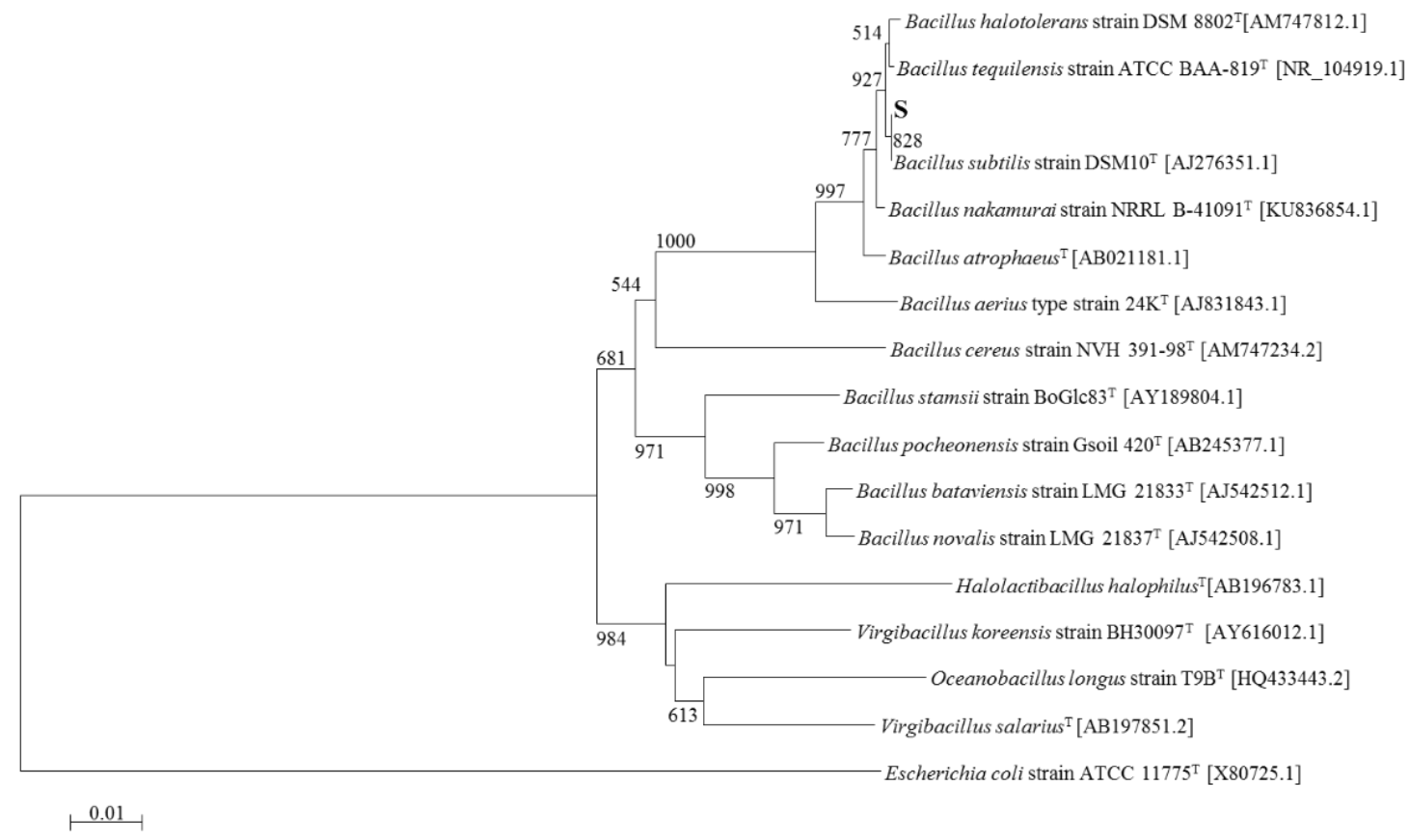

Figure 2 Neighbour-joining phylogenetic tree of the isolate MRH.13.S based on 16S rRNA sequences. The species names, strain numbers, and accession numbers are given. Bootstrap values greater than $50 \%$ are shown at the branch points. E. coli strain ATCC $11775^{\mathrm{T}}$ was used as an outgroup. Bar repesents 0.01 nucleotide divergence.

The abundance of this bacterial group is related not only to their cellulolytic and hemicellulolytic activities, but also to their role in the digestion of polysaccharides and aromatic compounds. The Bacilli take part in the early and intermediate steps of polymer degradation [37]. In addition, based on comparative genomic analysis, Bacillus subtilis and its sister species B. amyloliquefaciens have evolutionary traits for adaptation to plant-associated habitats [38]. Such finding might explain why we could find Bacillus as the dominant genus in the thermophilic phase of the composting process $[39,40]$. 


\section{Conclusions}

Termites from different nest type have different cellulolytic bacterial symbionts. Soil nester termites have higher culturable endoglucanase producing isolates than arboreal and wood nester. Thirty cellulolytic bacterial isolates have been isolated from 6 different species of termites on 3 different nest types, including 16 potential endoglucanase bacterial isolates. The cellulolytic index measured ranged from 1.16 - 4.89. Three isolates obtained representing the highest cellulolytic index from species representing each nest type were MRH.13.S, RH.13.AF, and MRH.13.O2. Isolate MRH.13.S had the closest relationship with Bacillus tequilensis (99\% homology) based on its 16S rRNA gene sequence. Meanwhile, isolates MRH.13.AF and MRH.13.O2 were identified as Bacillus spp. according to biochemical characterization.

\section{Acknowledgements}

The authors sincerely thank BBBRNP officers for their permission and assistance during the field survey and sampling. We would also like to show our gratitude to Mrs. Marryati Saparina for the assistance in the laboratory and Dr. Achmad Dinoto for the discussions and comments on the manuscript. This research was funded by Institute for Industrial Research and Standardization Pontianak, Indonesian Ministry of Industry.

\section{References}

[1] HMN Iqbal, G Kyazze and T Keshavarz. Advances in the valorization of lignocellulosic materials by biotechnology: An overview. BioResources 2013; 8, 3157-76.

[2] Z Anwar, M Gulfraz and M Irshad. Agro-industrial lignocellulosic biomass a key to unlock the future bio-energy: A brief review. J. Radiat. Res. Appl. Sci. 2014; 7, 163-73.

[3] M Bilal, M Asgher, HMN Iqbal, H Hu and X Zhang. Biotransformation of lignocellulosic materials into value-added products-a review. Int. J. Biol. Macromol. 2017; 98, 447-58.

[4] G Guerriero, JF Hausman, J Strauss, H Ertan and KS Siddiqui. Lignocellulosic biomass: Biosynthesis, degradation, and industrial utilization. Eng. Life Sci. 2016; 16, 1-16.

[5] L Auer, A Lazuka, D Sillam-Dussès, E Miambi, M O'Donohue and G Hernandez-Raquet. Uncovering the potential of termite gut microbiome for lignocellulose bioconversion in anaerobic batch bioreactors. Front. Microbiol. 2017; 8, 2623.

[6] P Eggleton. An introduction to termites: Biology, taxonomy and functional morphology. In: DE Bignell, Y Roisin and N Lo (Eds.). Biology of termites: A modern synthesis. Springer, Dordrecht, 2010, p. 1-26.

[7] A Thong-On, K Suzuki, S Noda, J Inoue, S Kajiwara and M Ohkuma. Isolation and characterization of anaerobic bacteria for symbiotic recycling of uric acid nitrogen in the gut of various termites. Microbes Environ. 2012; 27, 186-92.

[8] J Reuß, R Rachel, P Kämpfer, A Rabenstein, J Küver, S Dröge and H König. Isolation of methanotrophic bacteria from termite gut. Microbiol. Res. 2015; 179, 29-37.

[9] Z Pourramezan, G Ghezelbash, B Romani, S Ziaei and A Hedayatkhah. Screening and identification of newly isolated cellulose-degrading bacteria from the gut of xylophagous termite Microcerotermes diversus (Silvestri). Microbiologiia 2012; 81, 736-42.

[10] D Kavitha, K Vijayarani and K Kumanan. 16S rRNA typing of cellulolytic bacteria from the termite Odontotermes formosanus. Ind. J. Vet. Anim. Sci. Res. 2014; 43, 359-68.

[11] A Ferbiyanto, I Rusmana and R Raffiudin. Characterization and identification of cellulolytic bacteria from gut of worker Macrotermes gilvus. Hayati J. Biosci. 2015; 22, 197-200.

[12] RB Rosengaus, JE Moustakas, DV Calleri and JFA Traniello. Nesting ecology and cuticular microbial loads in dampwood (Zootermopsis angusticollis) and drywood termites (Incisitermes minor, I. schwarzi, Cryptotermes cavifrons). J. Insect Sci. 2003; 3, 31. 
http://wjst.wu.ac.th

[13] A Manjula, M Pushpanathan, S Sathyavathi, P Gunasekaran and J Rajendhran. Comparative analysis of microbial diversity in termite gut and termite nest using ion sequencing. Curr. Microbiol. 2016; 72, 267-75.

[14] Bukit Baka Bukit Raya National Park. Management portrait of Bukit Baka Bukit Raya National Park. Bukit Baka Bukit Raya National Park, Sintang, 2012, p. 3-16.

[15] Indonesian Agency for Meteorogy Climatology and Geophysics, Daily Climate Data for West Kalimantan Province, Availabe at: http://dataonline.bmkg.go.id/ketersediaan_data, accessed December 2016.

[16] M Ahmad. Key to the Indomalayan termites. Biologia 1958; 4, 119-8.

[17] M Ahmad. Termites (Isoptera) of Thailand. American Museum of Natural History, New York, USA, 1965, p. 1-113.

[18] Y Sornnuwat, C Vongkaluang and Y Takematsu. A systematic key to termites of Thailand. Kasetsart J. Nat. Sci. 2004; 38, 349-68.

[19] M Ramin, AR Alimon and N Abdullah. Identification of cellulolytic bacteria isolated from the termite Coptotermes curvignathus (Holmgren). J. Rapid Meth. Aut. Microbiol. 2009; 17, 103-16.

[20] RC Kasana, R Salwan, H Dhar, S Dutt and A Gulati. A rapid and easy method for the detection of microbial cellulases on agar plates using Gram's iodine. Curr. Microbiol. 2008; 57, 503-7.

[21] C Florencio, S Couri and CS Farinas. Correlation between agar plate screening and solid-state fermentation for the prediction of cellulase production by Trichoderma strains. Enzyme Res. 2012; 2012, 793708 .

[22] Y Nakagawa, T Sakane, M Suzuki and K Hatano. Phylogenetic structure of the genera Flexibacter, Flexithrix, and Microscilla deduced from 16S rRNA sequence analysis. J. Gen. Appl. Microbiol. 2002; 48, 155-65.

[23] F Jeanmougin, JD Thompson, M Gouy, DG Higgins and TJ Gibson. Multiple sequence alignment with Clustal X. Trends Biochem. Sci. 1998; 23, 403-5.

[24] SE Donovan, P Eggleton and DE Bignell. Gut content analysis and a new feeding group classification of termites. Ecol. Entomol. 2001; 26, 356-66.

[25] CG Liu, K Li, Y Wen, BY Geng, Q Liu and YH Lin. Bioethanol: New opportunities for an ancient product. In: Y Li and X Ge (Eds.). Advances in Bioenergy. Elsevier, USA, 2019.

[26] MA Postava-Davignon. 2010, Evolution and ecology of termite nesting behavior and its impact on disease susceptibility. Ph. D. Dissertasion. Northeastern University, Boston, USA.

[27] T Shankar, V Mariappan and L Isaiarasu. Screening cellulolytic bacteria from the mid-gut of the popular composting earthworm Eudrilus eugeniae (Kinberg). World J. Zool. 2011; 6, 142-8.

[28] P Sheng, S Huang, Q Wang, A Wang and H Zhang. Isolation, screening, and optimization of the fermentation conditions of highly cellulolytic bacteria from the hindgut of Holotrichia parallela larvae (Coleoptera: Scarabaeidae). Appl. Biochem. Biotechnol. 2012; 167, 270-84.

[29] L Adams and R Boopathy. Isolation and characterization of enteric bacteria from the hindgut of Formosan termite. Bioresource Technol. 2005; 96, 1592-8.

[30] P Gupta, K Samant and A Sahu. Isolation of cellulose-degrading bacteria and determination of their cellulolytic potential. Int. J. Microbiol. 2012; 2012, 578925.

[31] JL Balcázar, ID Blas, I Ruiz-Zarzuela, D Vendrell, O Girones and JL Muzquiz. Sequencing of variable regions of the $16 \mathrm{~S}$ rRNA gene for identification of lactic acid bacteria isolated from the intestinal microbiota of healthy salmonids. Comp. Immunol. Microbiol. Infect. Dis. 2007; 30, 111-8.

[32] JS Johnson, DJ Spakowicz, BY Hong, LM Petersen, P Demkowicz, L Chen, SR Leopold, BM Hanson, HO Agresta, M Gerstein, E Sodergren and GM Weinstock. Evaluation of 16S rRNA gene sequencing for species and strain-level microbiome analysis. Nat. Commun. 2019; 10, 5029.

[33] M Drancourt, C Bollet, A Carlioz, R Martelin, JP Gayral and D Raoult. 16S ribosomal DNA sequence analysis of a large collection of environmental and clinical unidentifiable bacterial isolates. J. Clin. Microbiol. 2000; 38, 3623-30.

[34] M Wenzel, I Schönig, M Berchtold, P Kämpfer and H König. Aerobic and facultatively anaerobic cellulolytic bacteria from the gut of the termite Zootermopsis angusticollis. J. Appl. Microbiol. 2002; 92, 32-40. 
[35] GM Mathew, YM Ju, CY Lai, DC Mathew and CC Huang. Microbial community analysis in the termite gut and fungus comb of Odontotermes formosanus: The implication of Bacillus as mutualists. FEMS Microbiol. Ecol. 2012; 79, 504-17.

[36] HRK Ali, NF Hemeda and YF Abdelaliem. Symbiotic cellulolytic bacteria from the gut of the subterranean termite Psammotermes hypostoma Desneux and their role in cellulose digestion. AMB Express 2019; 9, 111.

[37] H König. Bacillus species in the intestine of termites and other soil invertebrates. J. Appl. Microbiol. 2006; 101, 620-7.

[38] N Zhang, D Yang, JRA Kendall, R Borriss, IS Druzhinina, CP Kubicek, Q Shen and R Zhang. Comparative genomic analysis of Bacillus amyloliquefaciens and Bacillus subtilis reveals evolutional traits for adaptation to plant-associated habitats. Front. Microbiol. 2016; 7, 2039.

[39] A Amore, O Pepe, V Ventorino, A Aliberti and V Faraco. Cellulolytic Bacillus strains from natural habitats-a review. Chim. Oggi 2013; 31, 49-52.

[40] RK Rathnan, D John and T Balasaravanan. Isolation, screening, identification and optimized production of extracellular cellulase from Bacillus subtilis using cellulosic waste as carbon source. J. Microbiol. Biotechnol. Food Sci. 2013; 2, 2383-6. 